\title{
Human Sperm Cryopreservation: Update on Techniques, Effect on DNA Integrity, and Implications for ART
}

\author{
Marlea Di Santo, Nicoletta Tarozzi, Marco Nadalini, and Andrea Borini \\ Tecnobios Procreazione, Centre for Reproductive Health, Via Dante 15, 40125 Bologna, Italy \\ Correspondence should be addressed to Marlea Di Santo, disanto@tecnobiosprocreazione.it
}

Received 5 August 2011; Revised 22 September 2011; Accepted 27 September 2011

Academic Editor: James A. Brown

Copyright ( $) 2012$ Marlea Di Santo et al. This is an open access article distributed under the Creative Commons Attribution License, which permits unrestricted use, distribution, and reproduction in any medium, provided the original work is properly cited.

\begin{abstract}
Cryopreservation of human spermatozoa-introduced in the 1960's-has been recognized as an efficient procedure for management of male fertility before therapy for malignant diseases, vasectomy or surgical infertility treatments, to store donor and partner spermatozoa before assisted reproduction treatments and to ensure the recovery of a small number of spermatozoa in severe male factor infertility. Despite the usefulness of it, cryopreservation may lead to deleterious changes of sperm structure and function: while the effects of cryopreservation on cells are well documented, to date there is no agreement in the literature on whether or not cryopreservation affects sperm chromatin integrity or on the use of a unique and functional protocol for the freezing-thawing procedure. Therefore, sperm cryopreservation is an important component of fertility management and much of its successful application seems to affect the reproductive outcome of assisted reproduction technologies (ART): appropriate use of cryoprotectants before and sperm selection technologies after cryopreservation seem to have the greatest impact on preventing DNA fragmentation, thus improving sperm cryosurvival rates.
\end{abstract}

\section{Introduction}

The procedure that makes it possible to stabilize the cells at cryogenic temperatures is called cryopreservation, also known as an applied aspect of cryobiology or the study of life at low temperatures. Many advances in the cryopreservation technology have led to the development of methods that allow for low-temperature maintenance of a variety of cell types including male and female gametes, small multicellular organisms, and even more complex organisms such as embryos. Cryopreservation of human spermatozoaintroduced in the 1960's [1] — has overcome many space and time limitations and now forms integral part of assisted reproduction technologies (ARTs).

This technique becomes particularly important in cases of preservation of male fertility before radiotherapy or chemotherapy [2] which may lead to testicular failure or ejaculatory dysfunction. In fact, semen cryostorage seems to be the only proven method that may offer these couples a chance of having children in the future: cancer therapy could in fact lead to damage, resulting in subfertility or sterility due to gonad removal or permanent damage to germ cells caused by adjuvant therapy. In particular, the risk associated to therapy depends on several factors: the age of the patient at the time of treatment, the dose, site, and type of treatment [3]. Also some nonmalignant diseases, such as diabetes and autoimmune disorders, may lead to testicular damage. Cryopreservation is advisable also in these conditions [4]. In countries in which heterologous fertilization is allowed by law and in donor insemination programmes cryopreservation is necessary to have enough time to screen donors for infectious agents, such as the human immunodeficiency (HIV) and hepatitis B viruses, before the cryopreserved semen is used for clinical purposes [5]. In azoospermic patients, who have undergone testicular sperm extraction or percutaneous epididymal sperm aspiration, sperm cryostorage is also used to avoid repeated biopsies or aspirations [6]. Furthermore, cryopreservation is routinely performed in patients who-having to start an assisted reproduction treatment-decide to preemptively freeze the semen sample to avoid inconveniences due to failed ejaculation often associated with "semen collection stress," certain emotional states, or other commitments at the time of oocyte retrieval [7]. Finally, male gamete freezing is largely 
recommended to preserve fertility in those subjects whofor one reason or another-are exposed to potentially toxic agents which may interfere with gametogenesis [7].

\section{Techniques for Cryopreservation}

There are two main conventional freezing techniques used in sperm cryopreservation: slow freezing and rapid freezing

2.1. Slow Freezing. The slow freezing technique proposed by Behrman and Sawada [8] consists of progressive sperm cooling over a period of $2-4 \mathrm{~h}$ in two or three steps, either manually or automatically using a semiprogrammable freezer.

The manual method is performed by simultaneously decreasing the temperature of the semen while adding a cryoprotectant in a stepwise manner and after plunging the samples into liquid nitrogen [9]. It has been shown that the optimal initial cooling rate of the specimen from room temperature to $5^{\circ} \mathrm{C}$ is $0.5-1^{\circ} \mathrm{C} / \mathrm{min}$ [10]. The sample is then frozen from $5^{\circ} \mathrm{C}$ to $-80^{\circ} \mathrm{C}$ at a rate of $1-10^{\circ} \mathrm{C} / \mathrm{min}$. The specimen is then plunged into liquid nitrogen at $-196^{\circ} \mathrm{C}$ [11].

In spite of reports showing successful sperm freezing with manual techniques, the reproducibility of this procedure could pose some problems. For this reason, programmable freezers have been investigated [12]. The freezers use a plate to hold the straws; these are cooled by liquid nitrogen held in a storage tank under the plate. Liquid nitrogen is poured into the tank, and the machine, once programmed, uses the software data logging to obtain cooling from $20^{\circ} \mathrm{C}$ to $-80^{\circ} \mathrm{C}$ at rate of $1.5^{\circ} \mathrm{C} / \mathrm{min}$ and then at $6^{\circ} \mathrm{C} / \mathrm{min}$; at completion of the freezing the straws are removed and stored into liquid nitrogen at $-196^{\circ} \mathrm{C}$. This takes about $40 \mathrm{~min}$ [12]. Programmes are simple to use and allow for a cooling combination which does not require continuous operator intervention and have been used to increase the reproducibility of the freezing operations [12].

Some authors argue that conventional slow freezing, either manual or automated, causes extensive chemical-physical damage to the sperm probably because of ice crystallization [13].

2.2. Rapid Freezing. Rapid freezing was first proposed by Sherman [14]. This technique requires direct contact between the straws and the nitrogen vapours for $8-10 \mathrm{~min}$ and immersion in liquid nitrogen at $-196^{\circ} \mathrm{C}$. Inside nitrogen vapours there is a thermal gradient, as a function of the distance and the volume of the liquid below. The sample is initially mixed in dropwise manner with equal volume of cold cryoprotectant; the mixture is loaded into the straws and left to incubate at $4^{\circ} \mathrm{C}$ for 10 minutes. The straws are then placed at a distance of $15-20 \mathrm{~cm}$ above the level of liquid nitrogen $\left(-80^{\circ} \mathrm{C}\right)$ for $15 \mathrm{~min}$; after this stage, the straws are immersed in liquid nitrogen. During cooling it is preferable to place the straws in horizontal position to minimize the heat difference between the two ends. This technique has some drawbacks among which; for example, low reproducibility, indeed, the temperature drop curve cannot be controlled, and the freezing temperatures may vary from $-70,-80$, and $-99^{\circ} \mathrm{C}[7]$.

2.3. Cryopreservation of Small Numbers of Spermatozoa. The conventional methods of sperm cryopreservation described above are not ideal to cryopreserve small numbers of cells, such as epididymal and testicular spermatozoa. Efficient cryopreservation of surgically retrieved spermatozoa, as mentioned earlier in this chapter, reduces the number of surgical interventions and avoids the logistic problem associated with coordinating the women's oocyte retrieval and also the risk of no sperm being found on the day of oocyte retrieval [15]. Thus, novel cryopreservation approaches have been designed to cryopreserve limited numbers of motile sperms in a very small volume (Table 1). Both biological and nonbiological carriers have been tried for the cryopreservation of low numbers of spermatozoa, although, to date, no prospective randomised trials have been conducted to demonstrate that any single carrier is superior to the others [15]. Furthermore, to date there is a limited use of these technologies in the majority of IVF programs. This suggests that novel cryopreservation technology, designed to handle small sperm numbers and needs to be further explored [15]. Whatever the method used, to obtain good results it is essential to correctly perform all the steps before and after cryopreservation: the choice of more suitable cryoprotectants and the thawing procedure are particularly important.

2.4. Cryoprotectants. Cryoprotectants are low-molecularweight and highly permeable chemicals used to protect spermatozoa from freeze damage by ice crystallization. There are four main well-known cryoprotectants: glycerol, ethylene glycol, dimethyl sulphoxide, and 1,2-propanediol. Cryoprotectants act by decreasing the freezing point of a substance, reducing the amount of salts and solutes present in the liquid phase of the sample and by decreasing ice formation within the spermatozoa [16]. Usually the cryoprotectants are added in an equal volume of semen in a dropwise manner, gently mixed at room temperature, and then placed at $37^{\circ} \mathrm{C}$ for $10-15$ minutes to allow for proper equilibration between the cells and the medium [7]. It is necessary that the medium interacts with the cells. Indeed, the effectiveness of cryoprotecting substances is also a function of the time of interaction between the cryoprotectants and the cells [7]. Glycerol is the permeating cryoprotectant most widely used for human sperm acting on: the membrane structure, permeability and stability of the lipid bilayer, the association of surface proteins and the cellular metabolism. Its employment gives an unfavorable outcome on membrane and acrosome structure, although allowing the freezing of poor quality sperm [7]. Sherman's [14] studies showed that the use of glycerol may cause few alterations such as: presence of an undulating membrane, alteration in acrosomal internal membrane, nucleus inhomogeneity and disorganization in mitochondrial crests. Following this observations other protective substances were proposed such as the dimethyl sulfoxide (DMSO), which has deleterious effects on human 
TABLE 1: Approaches to cryopreserve limited number of spermatozoa.

\begin{tabular}{|c|c|c|c|c|}
\hline $\begin{array}{l}\text { Cryopreservation } \\
\text { techniques }\end{array}$ & Authors & Principle & Main advantages & Main disadvantages \\
\hline $\begin{array}{l}\text { Empty zona } \\
\text { pellucida }\end{array}$ & $\begin{array}{c}\text { Borini et al. [69] } \\
\text { Cohen et al. [70] } \\
\text { Walmsley et al. [71] } \\
\text { Montag et al. [72] } \\
\text { Hsieh et al. [73] } \\
\text { Liu et al. [74] } \\
\text { Levi-Setti et al. [75] } \\
\text { Cesana et al. [76] } \\
\text { Hassa et al. [77] }\end{array}$ & $\begin{array}{l}\text { Storage of individual } \\
\text { spermatozoa in animal or } \\
\text { human empty zona } \\
\text { pellucida. }\end{array}$ & $\begin{array}{l}\text { Avoid waste of time in } \\
\text { screening to locate motile } \\
\text { sperm; cryoprotectants can } \\
\text { be added and removed } \\
\text { without loss of } \\
\text { spermatozoa sequestered in } \\
\text { the zona }\end{array}$ & $\begin{array}{l}\text { Risk of biological } \\
\text { contamination }\end{array}$ \\
\hline Microdroplets & $\begin{array}{l}\text { Gil-Salom et al. [78] } \\
\text { Sereni et al. [79] } \\
\text { Quintans et al. [80] } \\
\text { Bouamama et al. [81] }\end{array}$ & $\begin{array}{l}\text { Storage of droplets of } \\
\text { sperm/cryoprotectants } \\
\text { mixture on the surface of } \\
\text { dry ice and directly plunged } \\
\text { into liquid nitrogen }\end{array}$ & $\begin{array}{l}\text { Avoid sperm loss through } \\
\text { adherence to the vessel }\end{array}$ & $\begin{array}{l}\text { Risk of cross-contamination; } \\
\text { shape and size of dishes make } \\
\text { difficult to handle and store in } \\
\text { conventional freezers and } \\
\text { liquid nitrogen tanks }\end{array}$ \\
\hline ICSI pipette & $\begin{array}{c}\text { Gvakharia et al. [82] } \\
\text { Sohn et al. }[83]\end{array}$ & $\begin{array}{l}\text { Storage of spermatozoa in } \\
\text { ICSI pipettes }\end{array}$ & $\begin{array}{l}\text { Sterile, simple, and } \\
\text { convenient system }\end{array}$ & $\begin{array}{l}\text { Not practical for long-term } \\
\text { storage; fragility of ICSI } \\
\text { pipettes; risk of } \\
\text { cross-contamination }\end{array}$ \\
\hline $\begin{array}{l}\text { Volvox globator } \\
\text { spheres }\end{array}$ & Just et al. [84] & $\begin{array}{l}\text { Storage of sperm into } \\
\text { spheres of Volvox globator }\end{array}$ & $\begin{array}{l}\text { Significant postthaw } \\
\text { recovery of motile sperm }\end{array}$ & $\begin{array}{l}\text { Exposure to genetic material } \\
\text { from the algae; constant } \\
\text { source of algae }\end{array}$ \\
\hline Alginate beads & Herrler et al. [85] & $\begin{array}{l}\text { Microencapsulation in } \\
\text { alginate beads }\end{array}$ & $\begin{array}{l}\text { Inert nature of alginate } \\
\text { beads }\end{array}$ & $\begin{array}{l}\text { Decrease sperm motility with } \\
\text { encapsulation }\end{array}$ \\
\hline Cryoloop & $\begin{array}{l}\text { Nawroth et al. [86] } \\
\text { Schuster et al. [87] } \\
\text { Isachenko et al. [42] } \\
\text { Isachenko et al. [42] } \\
\text { Desai et al. [88] } \\
\text { Desai et al. [89] } \\
\end{array}$ & $\begin{array}{l}\text { Individual spermatozoa } \\
\text { deposited directly on } \\
\text { cryoprotectant film } \\
\text { covering the nylon loop } \\
\text { and immersed in liquid } \\
\text { nitrogen }\end{array}$ & $\begin{array}{l}\text { Excellent vessel for } \\
\text { vitrification; no additional } \\
\text { preparation }\end{array}$ & $\begin{array}{l}\text { Open system: risk of } \\
\text { cross-contamination }\end{array}$ \\
\hline $\begin{array}{l}\text { Agarose } \\
\text { microspheres }\end{array}$ & Isaev et al. [90] & $\begin{array}{l}\text { Storage of sperm loaded in } \\
\text { agarose microspheres }\end{array}$ & Nonbiological carrier & $\begin{array}{l}\text { Clinical value of this approach } \\
\text { not evaluated }\end{array}$ \\
\hline Straws & $\begin{array}{c}\text { Desai et al. [91] } \\
\text { Isachenko et al. [92] } \\
\text { Koscinski et al. [93] }\end{array}$ & $\begin{array}{l}\text { Sperm/cryoprotectants } \\
\text { loaded into the ministraw }\end{array}$ & $\begin{array}{l}\text { Sterile, simple, and } \\
\text { convenient system }\end{array}$ & $\begin{array}{l}\text { Not ideal for severely impaired } \\
\text { specimens; sperm loss due to } \\
\text { adherence to the vessel }\end{array}$ \\
\hline
\end{tabular}

sperm when used at $4^{\circ} \mathrm{C}$, and the 1,2-propanediol slightly used in sperm cryopreservation [7].

2.5. Thawing Procedure. The thawing procedure is an equally important step: the cell must be allowed to recover its normal biological activities trying to avoid abrupt thermal changes as far as possible. Generally speaking, the cryopreservation protocols use a thawing temperature of $37^{\circ} \mathrm{C}$; even if higher thawing temperatures allow for more rapid heating, they are not used because of the risks associated to cell damage.

At the present time, several thawing techniques are used, among which are

(i) thawing at room temperature for $10 \mathrm{~min}$ and subsequent thermostat pass at $37^{\circ} \mathrm{C}$ for another $10 \mathrm{~min}$,

(ii) thawing in a thermostat and water-bath at $37^{\circ} \mathrm{C}$ for $10 \mathrm{~min}$, (iii) thawing at room temperature for $15 \mathrm{~min}$.

Once the semen is thawed, it is separated from the cryopreservation medium by washing in culture medium and centrifuging [7].

\section{Detrimental Effects of Cryopreservation on Sperm Integrity}

Compared with other cell types, spermatozoa seem to be less sensitive to cryopreservation damage because of the high fluidity of the membrane and the low water content (about $50 \%$ ). Despite this, cryopreservation may lead to deleterious changes of sperm structure and function [17]. It was largely reported that several damaging processes could occur during freezing-thawing of human spermatozoa, such as thermal shock with formation of intracellular and extracellular ice crystals, cellular dehydration, and osmotic shock [18]. 
The primary cause of cellular damage during cryopreservation is the formation of intracellular or extracellular ice crystals. During the freezing process, the cooling rate plays an important role in determining the extent of cryoinjury to the spermatozoa [9].

A rapid cooling rate causes severe intracellular ice formation, since the efflux of water across the membrane is impaired, thus, inducing supercooling.

Ice crystals formed breach the membranes and affect the organelle function. This condition leads to impaired cell survival. On the other hand, a too slow cooling rate determines the efflux of water from the internal to the external environment, increasing the concentration of solutes and the osmotic pressure. This condition leads to cell volume changes associated with the movement of water, dehydration, and toxicity damage due to high solute concentration [9]. Cryoinjury is not limited to the freezing process but may also occur during the thawing process as the ice melts or recrystallizes [9]. The phenomenon of recrystallization of both intracellular and extracellular ice, in frozen samples, occurs as smaller ice crystals with a rate of recrystallization that increases with increasing temperature [13].

It has largely been reported that chilling injury can modify the structure and integrity of plasma membranes $[19,20]$ mainly composed by phospholipids and cholesterol [21].

Even though high concentrations of cholesterol and polyunsaturated fatty acids give more fluidity to the membrane at lower temperature [22], during cryopreservation the cooling process causes phase transition of membrane lipids and impairs membrane protein function. In particular, the outer layer of the spermatozoal plasma membrane consists of a glycocalyx, a carbohydrate-rich zone that mainly contains oligosaccharide chains that bind to the integral protein of the plasma membrane (glycoproteins) or lipids (glycolipids) [23]. Generally, cryopreservation may have a detrimental effect changing the carbohydrate composition of the glycocalyx, thus impairing the function of membrane proteins which are responsible for ion transport and metabolism and affecting the fertilizing ability [24]: the glycocalyx is involved in some physiological functions such as immune protection of the female genital tract [25], acrosomal reaction [26], and early gamete interaction.

The plasma and mitochondrial membranes have the same susceptibility to cryopreservation [27]. Mitochondria are placed along the midpiece between the plasma membrane and the nine fibrous columns, to form a coating that provides energy necessary for sperm motility [27]. The greatest amount of energy is provided by molecules of ATP synthesized either by glycolysis in the cytoplasm [28] or through oxidative phosphorylation (oxphos) in the mitochondria [10].

The ATP generated by oxphos in the inner mitochondrial membrane is transferred to the microtubules, to drive motility [29]. Therefore, an impairment of mitochondrial activity may explain the reduction in motility [27].

An alteration in mitochondrial membrane fluidity may also lead to an alteration in mitochondrial membrane potential and release of ROS [9]. The peroxidative damage induced by increased concentration of ROS is associated with damage to the sperm plasma membrane and impairment of the axonemal structure [30]. In addition, cryopreservation has been shown to diminish the antioxidant activity of the spermatozoa making them more susceptible to ROS damage [31]. High concentration of ROS and fall of antioxidant enzymes lead to cell apoptosis [32]. In this context the apoptosis cascade is mediated by activation of the BCL2 family proteins: there is a permeabilization of the outer mitochondrial membrane through the Bax and BAK proteins and the release of cytochrome [33]. In turn, caspase 9 is activated along with APAF-1 to form an apoptosome [34]. The release of apoptosis-inducing factors from the mitochondria leads to DNA fragmentation [35]. Several studies examined the role of in vitro antioxidant supplementation in protecting the sperm DNA from oxidative damage. For example, when added to the seminal fluid during cryopreservation, genistein [36], resveratrol [37], and ascorbic acid [37] seem to reduce DNA damage; on the contrary, vitamin E [38], ascorbate, and catalase [39] seem to improve motility and reduce ROS levels, though they do not improve spermatozoal viability and do not reduce DNA damage. In any case, the number of these studies and the number of patients they include is still too limited to draw any conclusions on the efficacy of antioxidant supplementation in protecting DNA from freezing-induced damage.

3.1. Cryopreservation and DNA Damage. While the effects of cryopreservation on the fertilization capacity, motility, morphology, and viability of spermatozoa are well documented, still open is the question of the possible alteration of sperm DNA integrity after freezing-thawing procedures. There is no agreement in the literature neither on whether cryopreservation induces DNA damage nor on the amount of damage. In some studies, authors have reported significant alterations of sperm DNA integrity after cryopreservation/thawing $[6,40]$, whereas other studies have expressed a different opinion $[41,42]$. This controversy between one study and the other could first of all be explained by the fact that the findings do not refer to a considerable number of samples and is also due to the use of (1) different freezing procedures, (2) different tests to evaluate the DNA integrity, and (3) different semen preparation techniques before cryopreservation (i.e., swimup or density gradient centrifugation). For example, Donnelly and colleagues [6] investigated precryopreservation and postcryopreservation DNA integrity of both semen and prepared sperm samples (density gradient centrifugation or direct swimup) in 50 men. They reported that freezing sperm in seminal plasma improves postthaw DNA integrity: sperm-frozen unprepared in seminal fluid seems to be more resistant to freezing damage than frozen prepared sperm; further improvement can be achieved by preparing sperm and freezing after readdition of seminal plasma. This may be due to the presence of abundant antioxidants in seminal plasma. Concerning the variability linked to different freezing procedures, in the study of Petym and colleagues [43], the authors evaluated cryodamage on sperm chromatin comparing two different procedures: 
liquid nitrogen vapour versus computerized program freezer. They analyzed 50 semen samples using acridine orange and concluded that DNA damage was significantly higher following freezing with liquid nitrogen.

From a detailed analysis of the references currently available in the literature, it was found that there are basically three different lines of thought about the question: "Does the freezing-thawing procedure induce sperm DNA damage?".

According to several authors the answer is "YES" (Table 2(a)). Spano and his group [44] reported that overall sperm quality deteriorates after freezing-thawing, including sperm DNA integrity assessed by SCSA in 19 samples. These findings have been confirmed in a study by De Paula and colleagues [40] on 77 patients, where the authors have evaluated the degree of sperm DNA fragmentation by TUNEL assay before and after cryopreservation: the authors stressed that the freezing-thawing procedure negatively affects DNA integrity. Furthermore, from the data published in the literature, it is also clear that among the authors who argue that cryopreservation induces sperm DNA damage there is sometimes no agreement on the mechanism which actually induces that damage. For example, in spite of the fact that ROS was widely reported to play an important role in the pathophysiology of damage to human spermatozoa, including DNA fragmentation, Zribi and his group [45] stated that there is no relationship between DNA fragmentation and DNA oxidation. They suggested that cryopreservation induces sperm DNA fragmentation through other pathways beside oxidative stress, such as defects in DNA repairing enzymes or enhancement of defects already present in sperm cells. This hypothesis is controverted by Thomson and colleagues [46]: despite the use of the same technique to assess DNA oxidation, fluorescent assay for the detection of 8 oxoguanine, they reported that human sperm DNA fragmentation is associated with an increase in oxidative stress during cryopreservation, rather than the activation of caspase and apoptosis.

About the question "Does the freezing-thawing procedure induce sperm DNA damage?" some authors follow another line of thought and answer "YES, but with some conditions" (Table 2(b)). They support the hypothesis of less susceptibility to freezing damage in the spermatozoa of fertile men, classified using WHO criteria, than those of infertile men. In the study of Donnelly and colleagues [6], semen samples were obtained from 17 fertile and 40 infertile men, and sperm integrity was assessed before and after cryopreservation using the Comet assay. The authors showed that semen from fertile men appears to be more resistant to freezing damage than sample from infertile men; moreover, in fertile man, there was no significant decrease in DNA integrity after cryopreservation. These results support the observation that spermatozoa from infertile men have a greater incidence of irregular chromatin organization and show significantly decreased resistance to thermal denaturation compared with spermatozoa from fertile men [47, 48]. In fact, as a consequence of reduced protamination, poor-quality spermatozoa often contain partially decondensed chromatin that generates functional immaturity [6]. Chromatin condensation is fundamental for spermatozoa since spermatogenesis results in the discarding of cytoplasm, leaving the spermatozoa incapable of undertaking DNA repair. According to this hypothesis, Kalthur and colleagues [49], evaluating sperm morphology and sperm DNA damage before and after cryopreservation, reported that the susceptibility of morphologically abnormal sperm to DNA damage during the freezing process is significantly higher than that of sperm with normal morphology. They hypothesised that sperm with head abnormalities may have altered membrane physical properties and thereby have altered tolerance to cold stress. However, there are no studies conducted to assess whether or not a morphologically abnormal sperm can retain its chromatin integrity during cryopreservation.

In opposition to these two answers to the above question, there is a third line of thought: some authors say: "NO, the freezing-thawing procedure does not compromise sperm DNA integrity" (Table 2(c)). For example, Duru and his group [41] evaluated the effects of cryopreservation on DNA fragmentation and membrane integrity in 21 patients using the TUNEL assay and annexin V. Their results indicated that cryopreservation altered plasma membrane symmetry and was associated with translocation of phosphatidylserine, while DNA integrity was maintained. In addition, Isachenko and colleagues [42], comparing the effects of slow freezing and vitrification on sperm DNA integrity in the absence of cryoprotectant, found that the integrity of DNA is unaffected by cryopreservation. The lack of effects of cryopreservation on sperm DNA has also been confirmed by data of Paasch and colleagues [50]. They demonstrated that cryopreservation was significantly associated with disruption of the mitochondrial membrane potential, as well as activation of caspase 3,8 , and 9 , but no significant changes were observed in DNA fragmentation, as assessed by the TUNEL assay in 84 samples.

Even if the opinions on the issue of "cryopreservation and DNA damage" are still highly controversial, the evaluation of the impact of cryopreservation on sperm chromatin is of extreme importance. Likewise, sperm DNA integrity is an important factor for the success of ART [51-53].

\section{Cryopreservation and Reproductive Outcome}

Cryopreservation is widely known to raise impaired sperm motility and decrease fertilization rate through detrimental effects on membranes, acrosomal structure, and acrosin activity [54]. The freezing-thawing procedure of human spermatozoa may also be detrimental to the chromatin structure [55], leading to a potential risk of decondensation of the sperm nucleus after injection into the oocyte, thus, reducing fertilization rate [56]. However, a cumulative effect of cryopreservation on sperm fertilization capacity is not definitely established. Considering the decrease in sperm fertilization power induced by cryopreservation, it can be easily understood that intrauterine insemination and conventional in vitro fertilization (IVF) with frozen-thawed spermatozoa result in lower pregnancy rates compared with insemination with fresh sperm [1]: this is the reason why cryopreservation of semen samples before intrauterine insemination or conventional IVF is not recommended. 
TABLE 2: (a)-(c) Evaluation of DNA integrity after cryopreservation: description of the experimental design and conclusions.

(a)

\begin{tabular}{|c|c|c|c|c|}
\hline Authors & Test to evaluate DNA integrity & Number of samples & $\begin{array}{l}\text { Cryopreservation } \\
\text { method }\end{array}$ & $\begin{array}{c}\text { "Does the } \\
\text { freezing-thawing } \\
\text { procedure induce } \\
\text { sperm DNA damage?" }\end{array}$ \\
\hline Hamamah et al. [94] & $\begin{array}{l}\text { Acridine orange staining and } \\
\text { Feulgen-DNA quantitative } \\
\text { microspectrophotometry }\end{array}$ & 10 & Unspecified & Yes \\
\hline Spanò et al. [44] & SCSA + Acridine orange staining & 19 & $\begin{array}{l}\text { Equilibration at } 37^{\circ} \mathrm{C} \text {, } \\
\text { freezing in liquid } \\
\text { nitrogen vapour at } \\
-80^{\circ} \mathrm{C} \text { and then storage } \\
\text { in liquid nitrogen at } \\
-196^{\circ} \mathrm{C}\end{array}$ & Yes \\
\hline Hammadeh et al. [95] & Acridine orange staining & 59 & $\begin{array}{l}\text { Computerized } \\
\text { slow-stage freezer }+ \\
\text { static liquid nitrogen } \\
\text { vapour }\end{array}$ & Yes \\
\hline Donnelly et al. [6] & COMET assay & 40 & $\begin{array}{l}\text { Equilibration at } 37^{\circ} \mathrm{C} \text {, } \\
\text { freezing in liquid } \\
\text { nitrogen vapour at } \\
-80^{\circ} \mathrm{C} \text { and then storage } \\
\text { in liquid nitrogen at } \\
-196^{\circ} \mathrm{C}\end{array}$ & Yes \\
\hline Gandini et al. [96] & Acridine orange staining & 19 & $\begin{array}{l}\text { Equilibration at } 37^{\circ} \mathrm{C} \text {, } \\
\text { freezing in liquid } \\
\text { nitrogen vapour at } \\
-80^{\circ} \mathrm{C} \text { and then storage } \\
\text { in liquid nitrogen at } \\
-196^{\circ} \mathrm{C}\end{array}$ & Yes \\
\hline de Paula et al. [40] & TUNEL assay & $\begin{array}{l}\text { 77: (i) } 30 \\
\text { normozoospermic } \\
\text { (ii) } 47 \\
\text { oligozoospermic }\end{array}$ & $\begin{array}{l}\text { Use of freezer at }-20^{\circ} \mathrm{C} \text {, } \\
\text { freezing in liquid } \\
\text { nitrogen vapour, then } \\
\text { storage in liquid } \\
\text { nitrogen }-196^{\circ} \mathrm{C}\end{array}$ & Yes \\
\hline $\begin{array}{l}\text { Petyim and } \\
\text { Choavaratana [43] }\end{array}$ & Acridine orange staining & 50 & $\begin{array}{l}\text { Freezing with liquid } \\
\text { nitrogen vapour }+ \\
\text { computerized program } \\
\text { freezer }\end{array}$ & Yes \\
\hline $\begin{array}{l}\text { Nagamwuttiwong and } \\
\text { Kunathikom [97] }\end{array}$ & Acridine orange staining & 20 & $\begin{array}{l}\text { Freezing with liquid } \\
\text { nitrogen vapour }\end{array}$ & Yes \\
\hline $\begin{array}{l}\text { Dejarkom and } \\
\text { Kunathikom [98] }\end{array}$ & Acridine orange staining & 20 & $\begin{array}{l}\text { Computerized } \\
\text { controlled rate freezing }\end{array}$ & Yes \\
\hline Thomson et al. [46] & TUNEL assay & 60 & $\begin{array}{l}\text { Use of programmable } \\
\text { freezer }\end{array}$ & Yes \\
\hline Thomson et al. [46] & TUNEL assay & 320 & $\begin{array}{l}\text { Sample frozen with and } \\
\text { without cryoprotectant } \\
\text { by slow-controlled-rate } \\
\text { method using a } \\
\text { programmable freezer }\end{array}$ & Yes \\
\hline Zribi et al. [45] & TUNEL assay & 15 & $\begin{array}{l}\text { Equilibration at } 37^{\circ} \mathrm{C} \text {, } \\
\text { freezing in liquid } \\
\text { nitrogen vapour at } \\
-80^{\circ} \mathrm{C} \text {, then storage in } \\
\text { liquid nitrogen at } \\
-196^{\circ} \mathrm{C}\end{array}$ & Yes \\
\hline
\end{tabular}


(b)

\begin{tabular}{|c|c|c|c|c|}
\hline Authors & Test to evaluate DNA integrity & Number of samples & $\begin{array}{l}\text { Cryopreservation } \\
\text { technique }\end{array}$ & $\begin{array}{c}\text { "Does the freezing-thawing } \\
\text { procedure induce sperm } \\
\text { DNA damage?" }\end{array}$ \\
\hline $\begin{array}{l}\text { Donnelly } \\
\text { et al. [6] }\end{array}$ & COMET assay & $\begin{array}{l}\text { 57: (i) } 17 \text { fertile (ii) } 40 \\
\text { infertile }\end{array}$ & $\begin{array}{l}\text { Equilibration at } \\
37^{\circ} \mathrm{C} \text {, freezing in } \\
\text { liquid nitrogen } \\
\text { vapour at }-80 \circ \mathrm{C} \text {, } \\
\text { then storage in } \\
\text { liquid nitrogen at } \\
-196^{\circ} \mathrm{C}\end{array}$ & $\begin{array}{l}\text { Yes, but semen from fertile } \\
\text { men appears to be more } \\
\text { resistant to freezing damage }\end{array}$ \\
\hline $\begin{array}{l}\text { Kalthur } \\
\text { et al. [49] }\end{array}$ & $\begin{array}{c}\text { COMET assay + Acridine orange } \\
\text { staining }\end{array}$ & 44 & $\begin{array}{l}\text { Equilibration at } \\
37^{\circ} \mathrm{C} \text {, static cooling } \\
\text { at } 4^{\circ} \mathrm{C} \text {, cooling } \\
\text { vapour phase, then } \\
\text { storage in liquid } \\
\text { nitrogen at }-196^{\circ} \mathrm{C}\end{array}$ & $\begin{array}{l}\text { Yes, but morphologically } \\
\text { abnormal sperms seems to } \\
\text { be less resistant to freezing } \\
\text { damage }\end{array}$ \\
\hline $\begin{array}{l}\text { Ahmad } \\
\text { et al. [99] }\end{array}$ & COMET assay & $\begin{array}{l}\text { 196: (i) } 30 \\
\text { normospermic (ii) } \\
166 \text { infertile }\end{array}$ & $\begin{array}{l}\text { Freezing with } \\
\text { static-phase } \\
\text { vapour cooling } \\
\text { procedure }\end{array}$ & $\begin{array}{l}\text { Yes, but the sperm DNA } \\
\text { integrity of frozen samples } \\
\text { of fertile men is higher }\end{array}$ \\
\hline
\end{tabular}

(c)

\begin{tabular}{|c|c|c|c|c|}
\hline Authors & $\begin{array}{l}\text { Test to evaluate the DNA } \\
\text { integrity }\end{array}$ & Number of samples & Cryopreservation technique & $\begin{array}{c}\text { "Does the } \\
\text { freezing-thawing } \\
\text { procedure induce } \\
\text { sperm DNA damage?" }\end{array}$ \\
\hline $\begin{array}{l}\text { Høst } \\
\text { et al. [100] }\end{array}$ & $\begin{array}{l}\text { Immunoperoxidase detection of } \\
\text { digoxigenin-labelled genomic } \\
\text { DNA }\end{array}$ & $\begin{array}{l}\text { 53: (i) } 20 \text { fertile (ii) } 33 \\
\text { infertile }\end{array}$ & Conventional cryopreservation & No \\
\hline $\begin{array}{l}\text { Steele } \\
\text { et al. [101] }\end{array}$ & COMET assay & $\begin{array}{l}\text { 21: (i) } 9 \text { control (ii) } \\
12 \text { with obstructive } \\
\text { azoospermia }\end{array}$ & $\begin{array}{l}\text { Freezing in liquid nitrogen } \\
\text { vapour }\end{array}$ & No \\
\hline $\begin{array}{l}\text { Duru } \\
\text { et al. [41] }\end{array}$ & TUNEL assay + annexin V & 21 & $\begin{array}{l}\text { Equilibration at } 37^{\circ} \mathrm{C} \text {, freezing in } \\
\text { liquid nitrogen vapour at }-80^{\circ} \mathrm{C} \text {, } \\
\text { then storage in liquid nitrogen at } \\
-196^{\circ} \mathrm{C}\end{array}$ & No \\
\hline $\begin{array}{l}\text { Isachenko } \\
\text { et al. [42] }\end{array}$ & COMET assay & 18 & $\begin{array}{l}\text { Programmable slow freezing }+ \\
\text { vitrification }\end{array}$ & No \\
\hline $\begin{array}{l}\text { Paasch } \\
\text { et al. [50] }\end{array}$ & $\begin{array}{l}\text { TUNEL assay + flow cytometric } \\
\text { kit for apoptosis }\end{array}$ & 84 & $\begin{array}{l}\text { Freezing at }-20^{\circ} \mathrm{C} \text {, freezing in } \\
\text { liquid nitrogen vapor at }-100^{\circ} \mathrm{C} \text {, } \\
\text { then storage in liquid nitrogen at } \\
-196^{\circ} \mathrm{C}\end{array}$ & No \\
\hline
\end{tabular}

The considerations are different for intracytoplasmic sperm injection (ICSI), because this procedure requires only a small number of motile spermatozoa for successful fertilization. Therefore, the current question is whether using fresh rather than cryopreserved sperm cells has the same effect on reproductive outcome in ICSI. To date, only a few large-scale studies on ICSI reproductive outcome comparing fresh and frozen-thawed human ejaculated, testicular, or epididymal spermatozoa have been reported in the literature, and the results seem to differ between the authors also depending on the origin of the employed spermatozoa.

4.1. Testicular Spermatozoa. Friedler and colleagues [57] reported no statistically significant differences in all parameters examined (fertilization rate, cleavage rate, embryo quality, implantation rate, clinical pregnancy rate, and ongoing pregnancy rate) between ICSI cycles with fresh or cryopreserved testicular spermatozoa from the same patients, comparing all ICSI cycles performed with fresh (25 cycles) and thawed (14 cycles) testicular spermatozoa, respectively. This hypothesis is supported by the study of some authors: Ben Rhouma and colleagues [58] performed a total of 60 ICSI cycles with fresh ( 32 cycles) and thawed (28 cycles) testicular spermatozoa; Habermann and colleagues [59] performed a total of 46 ICSI cycles with fresh (12 cycles) and thawed (34 cycles) testicular spermatozoa; Huang and colleagues [60] performed a total of 22 ICSI cycles with fresh (14 cycles) and thawed (8 cycles) testicular spermatozoa. All the authors reported the same results: the reproductive outcome of ICSI with frozen-thawed testicular spermatozoa is 
comparable with the reproductive outcome of ICSI obtained with fresh testicular spermatozoa. In contrast, De Croo and colleagues [61] stated that fertilization, implantation, and live-birth rates per embryo transfer are significantly lower after ICSI with frozen-thawed (35 cycles) than those with fresh (65 cycles) testicular spermatozoa.

4.2. Epididymal Spermatozoa. On the other hand, some groups compared the results of intracytoplasmic sperm injection (ICSI) with fresh and frozen-thawed epididymal spermatozoa. For example, Tournaye and colleagues [62] reported that the clinical pregnancy rate in ICSI cycles was comparable between fresh (157 cycles) and frozen-thawed (118 cycles) epididymal spermatozoa. Sukcharoen and colleagues [63] performed a total of 53 ICSI cycles with fresh (40 cycles) and thawed (13 cycles) epididymal spermatozoa and came to the same conclusion; also Cayan and colleagues [64] supported the same opinion. In opposition Shibahara and colleagues [65] stated that there was a significant difference in all reproductive parameters examined between ICSI cycles with fresh or cryopreserved epididymal spermatozoa, comparing ICSI cycles performed with fresh (5 cycles) and thawed (13 cycles) epididymal spermatozoa.

4.3. Ejaculated Spermatozoa. The majority of studies on cryopreservation and ICSI reproductive outcome were conducted using spermatozoa of testicular or epididymal origin. Only two major groups reported data on fertilization and pregnancy rates after ICSI comparing fresh and frozenthawed human ejaculated spermatozoa. First, Kucznynski and colleagues [66] compared the reproductive outcome of 118 ICSI cycles using fresh spermatozoa and 122 ICSI cycles using frozen-thawed spermatozoa, all from oligoasthenoteratozoospermic patients. The authors did not report of any statistically significant differences in fertilization rate between the two groups of patients. Moreover, these data show that values of ongoing pregnancies are significantly higher in ICSI patients when human sperm samples are cryopreserved. According to Ragni and his group [67], this suggests that properly performed cryopreservation selectively affects defective rather than normal spermatozoa [44]. This observation seems to indicate that cryopreservation before ICSI might be helpful to eliminate senescent or deficient spermatozoa, thus, improving reproductive outcome [62]. Borges and his group [68] also investigated sperm cryopreservation effects on ICSI outcome. The author compared 61 and 79 ICSI cycles performed with cryopreserved and fresh ejaculated spermatozoa and, in particular, examined the reproductive outcome obtained using semen samples with decreased and with normal motility. Results demonstrated that (1) using semen with normal motility the reproductive outcome obtained using fresh or frozenthawed spermatozoa is the same; (2) in semen with decreased motility the fertilization rate with fresh sperm was higher than that with the cryopreserved one, but no differences were detected in implantation and pregnancy. This finding supports the hypothesis that the freezing-thawing procedure causes more damage in patients with alterations in semen quality than that in patients with normal semen. However, once the oocyte is fertilized, implantation and pregnancy rates are similar in patients with or without sperm anomalies.

\section{Conclusion}

Today, sperm cryopreservation is widely used to store donor and partner spermatozoa before assisted reproduction treatments, to preserve spermatozoa before therapy for malignant diseases, vasectomy, or surgical infertility treatments and to ensure the recovery of a small number of spermatozoa in severe male factor infertility. Therefore, sperm cryopreservation is an important component of fertility management, and much of its successful application seems to affect the reproductive outcome of ART.

While the effects of cryopreservation on cells are well documented, to date there is no agreement in the literature on whether or not cryopreservation affects sperm chromatin integrity or on the use of a unique and functional protocol for the freezing-thawing procedure. This suggests that, to date, it would be useful to perform a multicenter study with large numbers of semen specimens which could be processed using unique freezing protocols. Moreover, though further investigations are needed to fully understand the real influence of cryopreservation on sperm DNA integrity and the impact of the use of cryopreserved spermatozoa on the reproductive outcome, technical measures should be applied to provide maximum protection to the male gametes: appropriate use of cryoprotectants before and sperm selection technologies after cryopreservation seems to have the greatest impact on preventing DNA fragmentation, thus improving sperm cryosurvival rates.

\section{References}

[1] J. K. Sherman, "Synopsis of the use of frozen human semen since 1964: state of the art of human semen banking," Fertility and Sterility, vol. 24, no. 5, pp. 397-412, 1973.

[2] W. G. Sanger, J. H. Olson, and J. K. Sherman, "Semen cryobanking for men with cancer-Criteria change," Fertility and Sterility, vol. 58, no. 5, pp. 1024-1027, 1992.

[3] J. R. Jensen, D. E. Morbeck, and C. C. Coddington III, "Fertility preservation," Mayo Clinic Proceedings, vol. 86, no. 1, pp. 45-49, 2011.

[4] J. T. Anger, B. R. Gilbert, and M. Goldstein, "Cryopreservation of sperm: indications, methods and results," Journal of Urology, vol. 170, no. 4 I, pp. 1079-1084, 2003.

[5] G. J. Morris, E. Acton, and S. Avery, "A novel approach to sperm cryopreservation," Human Reproduction, vol. 14, no. 4, pp. 1013-1021, 1999.

[6] E. T. Donnelly, N. McClure, and S. E. M. Lewis, "Cryopreservation of human semen and prepared sperm: effects on motility parameters and DNA integrity," Fertility and Sterility, vol. 76, no. 5, pp. 892-900, 2001.

[7] R. Fabbri, P. Ciotti, B. Di Tommaso et al., "Tecniche di crioconservazione riproduttiva," Rivista Italiana di Ostetricia e Ginecologia, vol. 3, pp. 33-41, 2004.

[8] S. J. Behrman and Y. Sawada, "Heterologous and homologous inseminations with human semen frozen and stored in a liquid-nitrogen refrigerator," Fertility and Sterility, vol. 17, no. 4, pp. 457-466, 1966. 
[9] T. M. Said, A. Gaglani, and A. Agarwal, "Implication of apoptosis in sperm cryoinjury," Reproductive BioMedicine Online, vol. 21, no. 4, pp. 456-462, 2010.

[10] M. Mahadevan and A. O. Trounson, "Effect of cooling, freezing and thawing rates and storage conditions on preservation of human spermatozoa," Andrologia, vol. 16, no. 1, pp. 52-60, 1984.

[11] J. V. Thachil and M. A. S. Jewett, "Preservation techniques for human semen," Fertility and Sterility, vol. 35, no. 5, pp. 546-548, 1981.

[12] W. V. Holt, "Basic aspects of frozen storage of semen," Animal Reproduction Science, vol. 62, no. 1-3, pp. 3-22, 2000.

[13] P. Mazur, W. F. Rall, and N. Rigopoulos, "Relative contributions of the fraction of unfrozen water and of salt concentration to the survival of slowly frozen human erythrocytes," Biophysical Journal, vol. 36, no. 3, pp. 653-675, 1981.

[14] J. Sherman, "Cryopreservation of human semen," in Handbook of the Laboratory Diagnosis and Treatment of Infertility, B. Keel and B. W. Webster, Eds., CRC Press, Boca Raton, Fla, USA, 1990.

[15] F. Abdelhafez, M. Bedaiwy, S. A. El-Nashar, E. Sabanegh, and N. Desai, "Techniques for cryopreservation of individual or small numbers of human spermatozoa: a systematic review," Human Reproduction Update, vol. 15, no. 2, pp. 153-164, 2009.

[16] D. Royere, C. Barthelemy, S. Hamamah, and J. Lansac, "Cryopreservation of spermatozoa: a 1996 review," Human Reproduction Update, vol. 2, no. 6, pp. 553-559, 1996.

[17] P. F. Watson, "The causes of reduced fertility with cryopreserved semen," Animal Reproduction Science, vol. 60-61, pp. 481-492, 2000.

[18] P. Stanic, M. Tandara, Z. Sonicki, V. Simunic, B. Radakovic, and E. Suchanek, "Comparison of protective media and freezing techniques for cryopreservation of human semen," European Journal of Obstetrics Gynecology and Reproductive Biology, vol. 91, no. 1, pp. 65-70, 2000.

[19] A. Arav, Y. Zeron, S. B. Leslie, E. Behboodi, G. B. Anderson, and J. H. Crowe, "Phase transition temperature and chilling sensitivity of bovine oocytes," Cryobiology, vol. 33, no. 6, pp. 589-599, 1996.

[20] Y. Zeron, M. Pearl, A. Borochov, and A. Arav, "Kinetic and temporal factors influence chilling injury to germinal vesicle and mature bovine oocytes," Cryobiology, vol. 38, no. 1, pp. 35-42, 1999.

[21] M. N. Giraud, C. Motta, D. Boucher, and G. Grizard, "Membrane fluidity predicts the outcome of cryopreservation of human spermatozoa," Human Reproduction, vol. 15, no. 10, pp. 2160-2164, 2000.

[22] P. J. Quinn, "A lipid-phase separation model of lowtemperature damage to biological membranes," Cryobiology, vol. 22, no. 2, pp. 128-146, 1985.

[23] T. Talaei, T. Esmaeelpour, F. Aekiyash, and S. Bahmanpour, "Effects of cryopreservation on plasma membrane glycoconjugates of human spermatozoa," Iranian Journal of Reproductive Medicine, vol. 8, no. 3, pp. 119-124, 2010.

[24] S. Benoff, "Carbohydrates and fertilization: an overview," Molecular Human Reproduction, vol. 3, no. 7, pp. 599-637, 1997.

[25] N. L. Cross and J. W. Overstreet, "Glycoconjugates of the human sperm surface: distribution and alterations that accompany capacitation in vitro," Gamete Research, vol. 16, no. 1, pp. 23-35, 1987.

[26] B. Lassalle and J. Testart, "Human zona pellucida recognition associated with removal of sialic acid from human sperm surface," Journal of Reproduction and Fertility, vol. 101, no. 3, pp. 703-711, 1994.

[27] M. O'Connell, N. McClure, and S. E. M. Lewis, "The effects of cryopreservation on sperm morphology, motility and mitochondrial function," Human Reproduction, vol. 17, no. 3, pp. 704-709, 2002.

[28] W. C. L. Ford and J. M. Rees, "The bioenergetics of mammalian sperm motility," in Controls of Sperm Motility: Biological and Clinical Aspects, C. Gagnon, Ed., pp. 175-202, CRC Press, Boca Raton, Fla, USA, 1990.

[29] L. Zamboni, "The ultrastructural pathology of the spermatozoon as a cause of infertility: the role of electron microscopy in the evaluation of semen quality," Fertility and Sterility, vol. 48, no. 5, pp. 711-734, 1987.

[30] R. A. Saleh and A. Agarwal, "Oxidative stress and male infertility: from research bench to clinical practice," Journal of Andrology, vol. 23, no. 6, pp. 737-752, 2002.

[31] J. L. Lasso, E. E. Noiles, J. G. Alvarez, and B. T. Storey, "Mechanism of superoxide dismutase loss from human sperm cells during cryopreservation," Journal of Andrology, vol. 15, no. 3, pp. 255-265, 1994.

[32] X. Wang, R. K. Sharma, S. C. Sikka, A. J. Thomas, T. Falcone, and A. Agarwal, "Oxidative stress is associated with increased apoptosis leading to spermatozoa DNA damage in patients with male factor infertility," Fertility and Sterility, vol. 80, no. 3, pp. 531-535, 2003.

[33] D. S. McClintock, M. T. Santore, V. Y. Lee et al., "Bc12 family members and functional electron transport chain regulate oxygen deprivation-induced cell death," Molecular and Cellular Biology, vol. 22, no. 1, pp. 94-104, 2002.

[34] D. Arnoult, B. Gaume, M. Karbowski, J. C. Sharpe, F. Cecconi, and R. J. Youle, "Mitochondrial release of AIF and EndoG requires caspase activation downstream of Bax/Bakmediated permeabilization," EMBO Journal, vol. 22, no. 17, pp. 4385-4399, 2003.

[35] G. Martin, N. Cagnon, O. Sabido et al., "Kinetics of occurrence of some features of apoptosis during the cryopreservation process of bovine spermatozoa," Human Reproduction, vol. 22, no. 2, pp. 380-388, 2007.

[36] J. C. Martinez-Soto, J. De Dioshourcade, A. GutiérrezAdán, J. L. Landeras, and J. Gadea, "Effect of genistein supplementation of thawing medium on characteristics of frozen human spermatozoa," Asian Journal of Andrology, vol. 12, no. 3, pp. 431-441, 2010.

[37] C. S. Branco, M. E. Garcez, F. F. Pasqualotto, B. Erdtman, and M. Salvador, "Resveratrol and ascorbic acid prevent DNA damage induced by cryopreservation in human semen," Cryobiology, vol. 60, no. 2, pp. 235-237, 2010.

[38] K. Taylor, P. Roberts, K. Sanders, and P. Burton, "Effect of antioxidant supplementation of cryopreservation medium on post-thaw integrity of human spermatozoa," Reproductive BioMedicine Online, vol. 18, no. 2, pp. 184-189, 2009.

[39] Z. Li, Q. Lin, R. Liu, W. Xiao, and W. Liu, "Protective effects of ascorbate and catalase on human spermatozoa during cryopreservation," Journal of Andrology, vol. 31, no. 5, pp. 437-444, 2010.

[40] T. S. de Paula, R. P. Bertolla, D. M. Spaine, M. A. Cunha, N. Schor, and A. P. Cedenho, "Effect of cryopreservation on sperm apoptotic deoxyribonucleic acid fragmentation in patients with oligozoospermia," Fertility and Sterility, vol. 86, no. 3, pp. 597-600, 2006.

[41] N. K. Duru, M. S. Morshedi, A. Schuffner, and S. Oehninger, "Cryopreservation-thawing of fractionated human spermatozoa is associated with membrane phosphatidylserine 
externalization and not DNA fragmentation," Journal of Andrology, vol. 22, no. 4, pp. 646-651, 2001.

[42] E. Isachenko, V. Isachenko, I. I. Katkov et al., "DNA integrity and motility of human spermatozoa after standard slow freezing versus cryoprotectant-free vitrification," Human Reproduction, vol. 19, no. 4, pp. 932-939, 2004.

[43] S. Petyim and R. Choavaratana, "Cryodamage on sperm chromatin according to different freezing methods, assessed by AO test," Journal of the Medical Association of Thailand, vol. 89, no. 3, pp. 306-313, 2006.

[44] M. Spanò, E. Cordelli, G. Leter, F. Lombardo, A. Lenzi, and L. Gandini, "Nuclear chromatin variations in human spermatozoa undergoing swim-up and cryopreservation evaluated by the flow cytometric sperm chromatin structure assay," Molecular Human Reproduction, vol. 5, no. 1, pp. 2937, 1999.

[45] N. Zribi, N. Feki Chakroun, H. El Euch, J. Gargouri, A. Bahloul, and L. Ammar Keskes, "Effects of cryopreservation on human sperm deoxyribonucleic acid integrity," Fertility and Sterility, vol. 93, no. 1, pp. 159-166, 2010.

[46] L. K. Thomson, S. D. Fleming, R. J. Aitken, G. N. De Iuliis, J. A. Zieschang, and A. M. Clark, "Cryopreservation-induced human sperm DNA damage is predominantly mediated by oxidative stress rather than apoptosis," Human Reproduction, vol. 24, no. 9, pp. 2061-2070, 2009.

[47] D. P. Evenson, Z. Darzynkiewicz, and M. R. Melamed, "Comparison of human and mouse sperm chromatin structure by flow cytometry," Chromosoma, vol. 78, no. 2, pp. 225-238, 1980.

[48] D. P. Evenson and M. R. Melamed, "Rapid analysis of normal and abnormal cell types in human semen and testis biopsies by flow cytometry," Journal of Histochemistry and Cytochemistry, vol. 31, no. 1 A, pp. 248-253, 1983.

[49] G. Kalthur, S. K. Adiga, D. Upadhya, S. Rao, and P. Kumar, "Effect of cryopreservation on sperm DNA integrity in patients with teratospermia," Fertility and Sterility, vol. 89, no. 6, pp. 1723-1727, 2008.

[50] U. Paasch, R. K. Sharma, A. K. Gupta et al., "Cryopreservation and thawing is associated with varying extent of activation of apoptotic machinery in subsets of ejaculated human spermatozoa," Biology of Reproduction, vol. 71, no. 6, pp. 1828-1837, 2004.

[51] R. J. Aitken and G. N. De Iuliis, "Origins and consequences of DNA damage in male germ cells," Reproductive BioMedicine Online, vol. 14, no. 6, pp. 727-733, 2007.

[52] N. Tarozzi, D. Bizzaro, C. Flamigni, and A. Borini, "Clinical relevance of sperm DNA damage in assisted reproduction," Reproductive BioMedicine Online, vol. 14, no. 6, pp. 746-757, 2007.

[53] A. Zini, J. M. Boman, E. Belzile, and A. Ciampi, "Sperm DNA damage is associated with an increased risk of pregnancy loss after IVF and ICSI: systematic review and meta-analysis," Human Reproduction, vol. 23, no. 12, pp. 2663-2668, 2008.

[54] N. L. Cross and S. E. Hanks, "Effects of cryopreservation on human sperm acrosomes," Human Reproduction, vol. 6, no. 9, pp. 1279-1283, 1991.

[55] D. Royere, S. Hamamah, J. C. Nicolle, and J. Lansac, "Chromatin alterations induced by freeze-thawing influence the fertilizing ability of human sperm," International Journal of Andrology, vol. 14, no. 5, pp. 328-332, 1991.

[56] D. Sakkas, F. Urner, P. G. Bianchi et al., "Sperm chromatin anomalies can influence decondensation after intracytoplasmic sperm injection," Human Reproduction, vol. 11, no. 4, pp. 837-843, 1996.
[57] S. Friedler, D. Strassburger, A. Raziel, D. Komarovsky, Y. Soffer, and R. Ron-El, "Intracytoplasmic injection of fresh and cryopreserved testicular spermatozoa in patients with nonobstructive azoospermia-A comparative study," Fertility and Sterility, vol. 68, no. 5, pp. 892-897, 1997.

[58] K. Ben Rhouma, H. Marrakchi, H. Khouja, K. Attalah, E. Ben Miled, and M. Sakly, "Outcome of intracytoplasmic injection of fresh and frozen-thawed testicular spermatozoa: a comparative study," Journal of Reproductive Medicine for the Obstetrician and Gynecologist, vol. 48, no. 5, pp. 349-354, 2003.

[59] H. Habermann, R. Seo, J. Cieslak, C. Niederberger, G. S. Prins, and L. Ross, "In vitro fertilization outcomes after intracytoplasmic sperm injection with fresh or frozenthawed testicular spermatozoa," Fertility and Sterility, vol. 73, no. 5, pp. 955-960, 2000.

[60] F. J. Huang, S. Y. Chang, M. Y. Tsai et al., "Clinical implications of intracytoplasmic sperm injection using cryopreserved testicular spermatozoa from men with azoospermia," Journal of Reproductive Medicine for the Obstetrician and Gynecologist, vol. 45, no. 4, pp. 310-316, 2000.

[61] I. D. Croo, J. Van Der Elst, K. Everaert, P. D. Sutter, and M. Dhont, "Fertilization, pregnancy and embryo implantation rates after ICSI with fresh or frozen-thawed testicular spermatozoa," Human Reproduction, vol. 13, no. 7, pp. 18931897, 1998.

[62] H. Tournaye, T. Merdad, S. Silber et al., "No differences in outcome after intracytoplasmic sperm injection with fresh or with frozen-thawed epididymal spermatozoa," Human Reproduction, vol. 14, no. 1, pp. 90-95, 1999.

[63] N. Sukcharoen, T. Sithipravej, S. Promviengchai, V. Chinpilas, and W. Boonkasemsanti, "Comparison of the outcome of intracytoplasmic sperm injection using fresh and frozenthawed epididymal spermatozoa obtained by percutaneous epididymal sperm aspiration," Journal of the Medical Association of Thailand, vol. 84, no. 1, pp. S331-S337, 2001.

[64] S. Cayan, D. Lee, J. Conaghan et al., "A comparison of ICSI outcomes with fresh and cryopreserved epididymal spermatozoa from the same couples," Human Reproduction, vol. 16, no. 3, pp. 495-499, 2001.

[65] H. Shibahara, Y. Hamada, A. Hasegawa et al., "Correlation between the motility of frozen-thawed epididymal spermatozoa and the outcome of intracytoplasmic sperm injection," International Journal of Andrology, vol. 22, no. 5, pp. 324-328, 1999.

[66] W. Kuczyski, M. Dhont, C. Grygoruk, D. Grochowski, S. Woczyski, and M. Szamatowicz, "The outcome of intracytoplasmic injection of fresh and cryopreserved ejaculated spermatozoa-A prospective randomized study," Human Reproduction, vol. 16, no. 10, pp. 2109-2113, 2001.

[67] G. Ragni, A. M. Caccamo, A. Dalla Serra, and S. Guercilena, "Computerized slow-staged freezing of semen from men with testicular tumors or Hodgkin's disease preserves sperm better than standard vapor freezing," Fertility and Sterility, vol. 53, no. 6, pp. 1072-1075, 1990.

[68] E. Borges Jr., L. M. Rossi, C. V. Locambo de Freitas et al., "Fertilization and pregnancy outcome after intracytoplasmic injection with fresh or cryopreserved ejaculated spermatozoa," Fertility and Sterility, vol. 87, no. 2, pp. 316-320, 2007.

[69] A. Borini, E. Sereni, M. A. Bonu, and C. Flamigni, "Freezing a few testicular spermatozoa retrieved by TESA," Molecular and Cellular Endocrinology, vol. 169, no. 1-2, pp. 27-32, 2000.

[70] J. Cohen, G. J. Garrisi, T. A. Congedo-Ferrara, K. A. Kieck, T. W. Sehimmel, and R. T. Scott, "Cryopreservation of single 
human spermatozoa," Human Reproduction, vol. 12, no. 5, pp. 994-1001, 1997.

[71] R. Walmsley, J. Cohen, T. Ferrara-Congedo, A. Reing, and J. Garrisi, "The first births and ongoing pregnancies associated with sperm cryopreservation within evacuated egg zonae," Human Reproduction, vol. 13, no. 4, pp. 61-70, 1998.

[72] M. Montag, K. Rink, U. Dieckmann, G. Delacrétaz, and H. Van Der Ven, "Laser-assisted cryopreservation of single human spermatozoa in cell- free zona pellucida," Andrologia, vol. 31, no. 1, pp. 49-53, 1999.

[73] Y. Y. Hsieh, H. D. Tsai, C. C. Chang, and H. Y. Lo, "Cryopreservation of human spermatozoa within human or mouse empty zona pellucidae," Fertility and Sterility, vol. 73, no. 4, pp. 694-698, 2000.

[74] J. Liu, X. Z. Zheng, T. A. Baramki, G. Compton, R. A. Yazigi, and E. Katz, "Cryopreservation of a small number of fresh human testicular spermatozoa and testicular spermatozoa cultured in vitro for 3 days in an empty zona pellucida," Journal of Andrology, vol. 21, no. 3, pp. 409-413, 2000.

[75] P. E. Levi-Setti, E. Albani, L. Negri, A. Cesana, P. Novara, and S. Bianchi, "Cryopreservation of a small number of spermatozoa in yolk-filled human zonae pellucidae," Archivio Italiano di Urologia e Andrologia, vol. 75, no. 4, pp. 195-198, 2003.

[76] A. Cesana, P. Novara, S. Bianchi et al., "Sperm cryopreservation in oligo-asthenospermic patients," in Proceedings of the 19th Annual Meeting of the European Society of Human Reproduction and Embryology, Madrid, Spain, July 2003.

[77] H. Hassa, F. Gurer, A. Yildirim, C. Can, V. Sahinturk, and B. Tekin, "A new protection solution for freezing small numbers of sperm inside empty zona pellucida: OsmangaziTurk solution," Cell Preservation Technology, vol. 4, no. 3, pp. 199-208, 2006.

[78] M. Gil-Salom, J. Romero, C. Rubio, A. Ruiz, J. Remohí, and A. Pellicer, "Intracytoplasmic sperm injection with cryopreserved testicular spermatozoa," Molecular and Cellular Endocrinology, vol. 169, no. 1-2, pp. 15-19, 2000.

[79] E. Sereni, M. A. Bonu, L. Fava et al., "Freezing spermatozoa obtained by testicular fine needle aspiration: a new technique," Reproductive BioMedicine Online, vol. 16, no. 1, pp. 89-95, 2008.

[80] C. Quintans, M. Donaldson, I. Asprea et al., "Development of a novel approach for cryopreservation of very small numbers of spermatozoa," Human Reproduction, vol. 15, p. 99, 2000.

[81] N. Bouamama, P. Briot, and J. Testart, "Comparison of two methods of cryoconservation of sperm when in very small numbers," Gynecologie Obstetrique Fertilite, vol. 31, no. 2, pp. 132-135, 2003.

[82] M. Gvakharia and G. Adamson, "A method of successful cryopreservation of small numbers of human spermatozoa," Fertility and Sterility, vol. 76, p. S101, 2001.

[83] J. O. Sohn, S. H. Jun, L. S. Park et al., "Comparison of recovery and viability of sperm in ICSI pipette after ultra rapid freezing or slow freezing," Fertility and Sterility, vol. 80, p. S128, 2003.

[84] A. Just, I. Gruber, M. Wöber, J. Lahodny, A. Obruca, and H. Strohmer, "Novel method for the cryopreservation of testicular sperm and ejaculated spermatozoa from patients with severe oligospermia: a pilot study," Fertility and Sterility, vol. 82, no. 2, pp. 445-447, 2004.

[85] A. Herrler, S. Eisner, V. Bach, U. Weissenborn, and H. M. Beier, "Cryopreservation of spermatozoa in alginic acid capsules," Fertility and Sterility, vol. 85, no. 1, pp. 208-213, 2006.
[86] F. Nawroth, V. Isachenko, S. Dessole et al., "Vitrification of human spermatozoa without cryoprotectants," Cryo-Letters, vol. 23, no. 2, pp. 93-102, 2002.

[87] T. G. Schuster, L. M. Keller, R. L. Dunn, D. A. Ohl, and G. D. Smith, "Ultra-rapid freezing of very low numbers of sperm using cryoloops," Human Reproduction, vol. 18, no. 4, pp. 788-795, 2003.

[88] N. Desai, C. Culler, and J. Goldfarb, "Cryopreservation of single sperm from epidydimal and testicular samples on cryoloops: preliminary case report," Fertility and Sterility, vol. 82, p. S264, 2004.

[89] N. N. Desai, H. Blackmon, and J. Goldfarb, "Single sperm cryopreservation on cryoloops: an alternative to hamster zona for freezing individual spermatozoa," Reproductive BioMedicine Online, vol. 9, no. 1, pp. 47-53, 2004.

[90] D. A. Isaev, S. Y. Zaletov, and W. Zaeva, "Artificial microcontainers for cryopreservation of solitary spermatozoa," in Proceedings of the 23rd Annual Meeting of the European Society of Human Reproduction and Embryology, p. 394, Lyon, France, July 2007.

[91] N. Desai, D. Glavan, and J. Goldfarb, "A convenient technique for cryopreservation of micro quantities of sperm," Fertility and Sterility, vol. 70, pp. S197-S198, 1998, Annual meeting program supplement.

[92] V. Isachenko, E. Isachenko, M. Montag et al., "Clean technique for cryoprotectant-free vitrification of human spermatozoa," Reproductive BioMedicine Online, vol. 10, no. 3, pp. 350-354, 2005.

[93] I. Koscinski, C. Wittemer, V. Lefebvre-Khalil, F. Marcelli, A. Defossez, and J. M. Rigot, "Optimal management of extreme oligozoospermia by an appropriate cryopreservation programme," Human Reproduction, vol. 22, no. 10, pp. 26792684, 2007.

[94] S. Hamamah, D. Royere, J. C. Nicolle, M. Paquignon, and J. Lansac, "Effects of freezing-thawing on the spermatozoon nucleus: a comparative chromatin cytophotometric study in the porcine and human species," Reproduction Nutrition Development, vol. 30, no. 1, pp. 59-64, 1990.

[95] M. E. Hammadeh, C. Dehn, M. Hippach et al., "Comparison between computerized slow-stage and static liquid nitrogen vapour freezing methods with respect to the deleterious effect on chromatin and morphology of spermatozoa from fertile and subfertile men," International Journal of Andrology, vol. 24, no. 2, pp. 66-72, 2001.

[96] L. Gandini, F. Lombardo, A. Lenzi, M. Spanò, and F. Dondero, "Cryopreservation and sperm DNA integrity," Cell and Tissue Banking, vol. 7, no. 2, pp. 91-98, 2006.

[97] T. Ngamwuttiwong and S. Kunathikom, "Evaluation of cryoinjury of sperm chromatin according to liquid nitrogen vapour method (I)," Journal of the Medical Association of Thailand, vol. 90, no. 2, pp. 224-228, 2007.

[98] S. Dejarkom and S. Kunathikom, "Evaluation of cryo-injury of sperm chromatin according to computer controlled rate freezing method part 2," Journal of the Medical Association of Thailand, vol. 90, no. 5, pp. 852-856, 2007.

[99] L. Ahmad, S. Jalali, S. A. Shami, Z. Akram, S. Batool, and O. Kalsoom, "Effects of cryopreservation on sperm DNA integrity in normospermic and four categories of infertile males," Systems Biology in Reproductive Medicine, vol. 56, no. 1, pp. 74-83, 2010.

[100] E. Høst, S. Lindenberg, J. A. Kahn, and F. Christensen, "DNA strand breaks in human sperm cells: a comparison between 
men with normal and oligozoospermic sperm samples," Acta Obstetricia et Gynecologica Scandinavica, vol. 78, no. 4, pp. 336-339, 1999.

[101] E. K. Steele, N. McClure, and S. E. M. Lewis, "Comparison of the effects of two methods of cryopreservation on testicular sperm DNA," Fertility and Sterility, vol. 74, no. 3, pp. 450$453,2000$. 


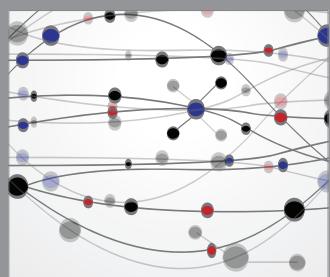

The Scientific World Journal
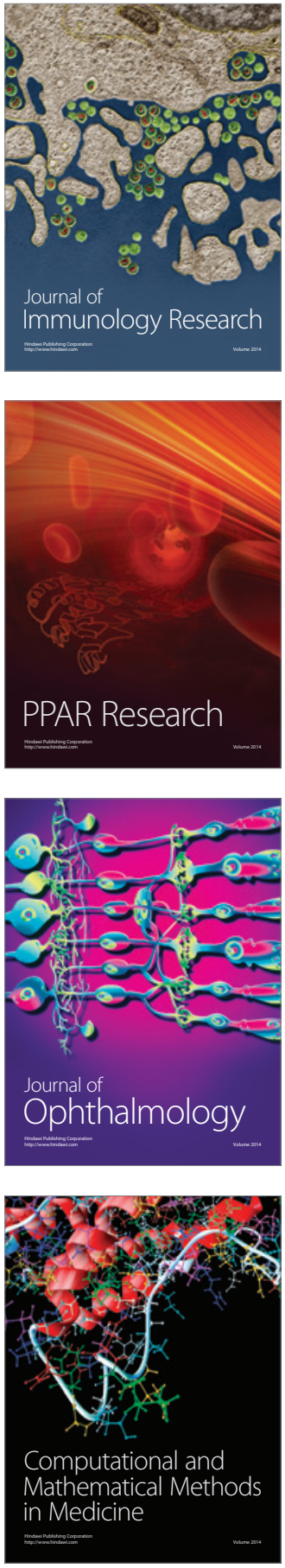

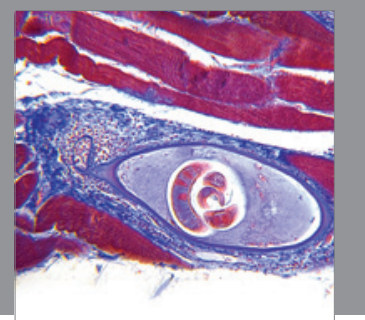

Gastroenterology

Research and Practice
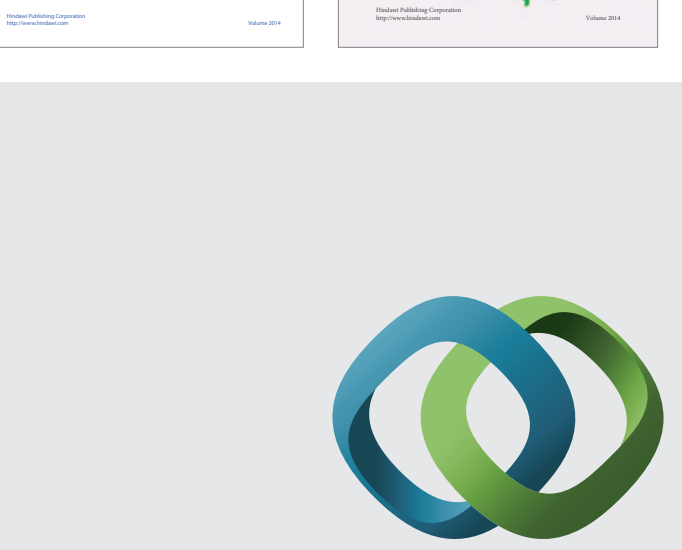

\section{Hindawi}

Submit your manuscripts at

http://www.hindawi.com
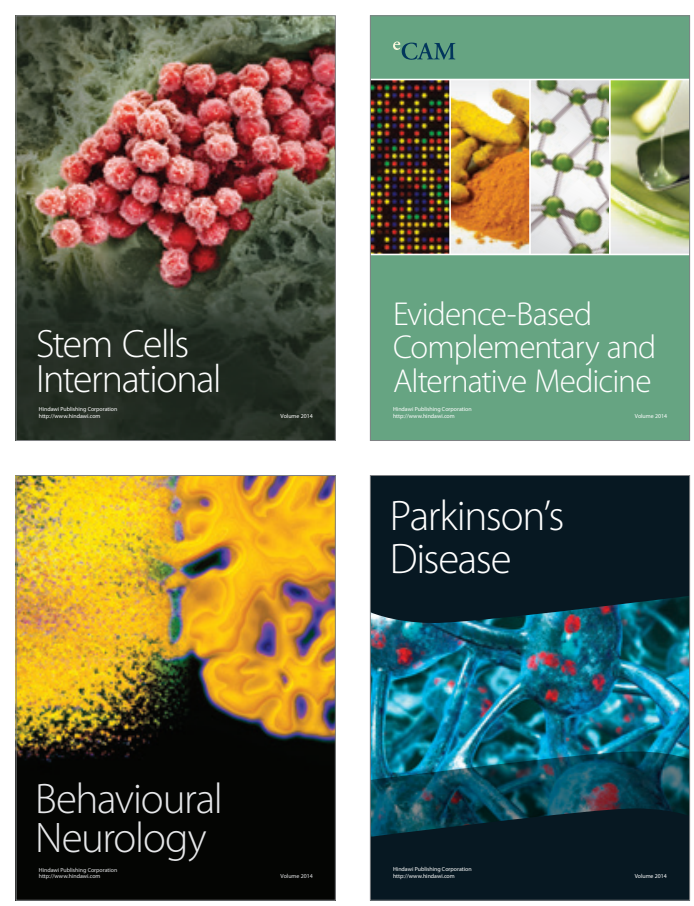

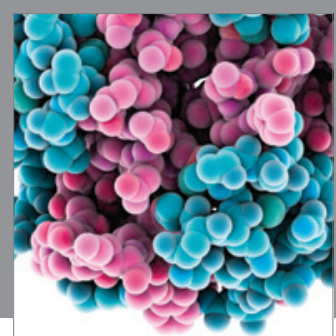

Journal of
Diabetes Research

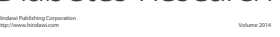

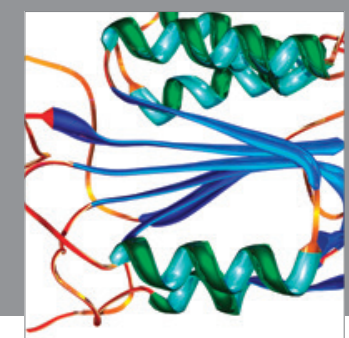

Disease Markers
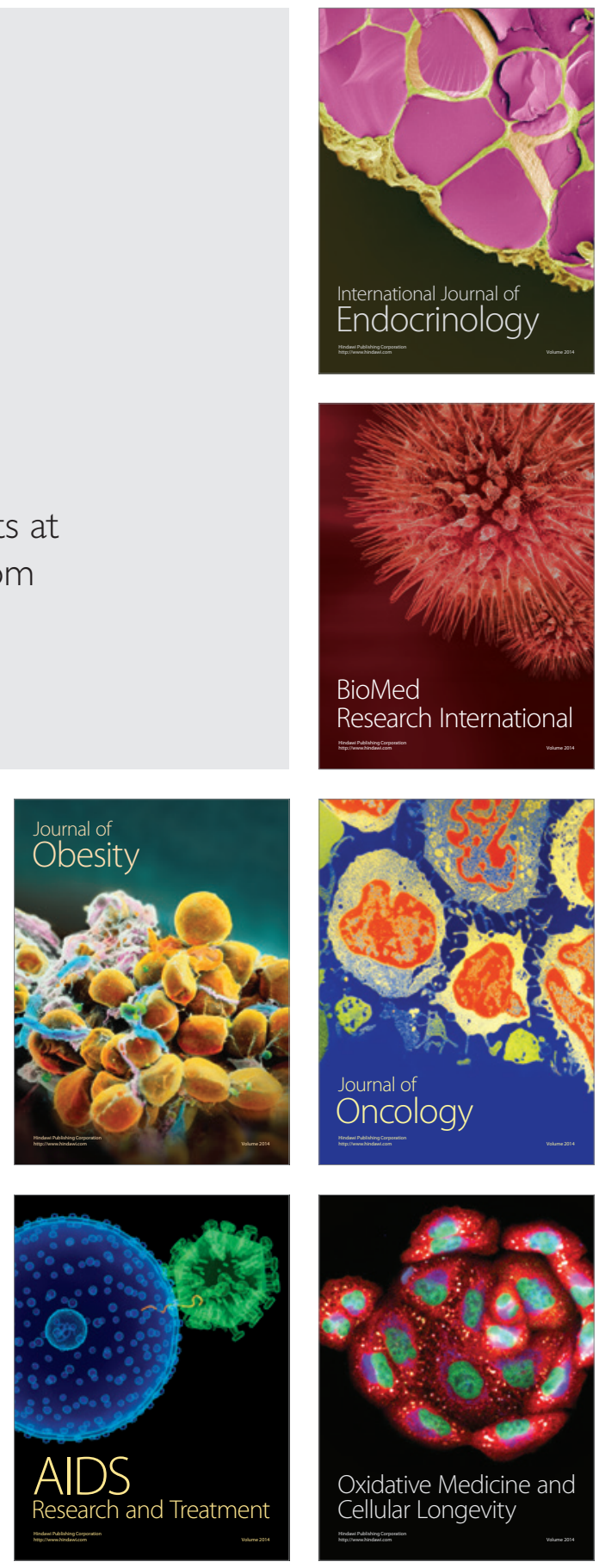